\title{
PENGEMBANGAN LEMBAR KERJA PESERTA DIDIK BERBASIS SAINTIFIK KONTEKSTUAL MATERI PERISTIWA ALAM BESERTA MITIGASI BENCANA
}

\author{
Encep Andriana ${ }^{1}$, Trian Pamungkas Alamsyah ${ }^{2}$, dan Injilya Tambun ${ }^{3}$ \\ PGSD FKIP Universitas Sultan Ageng Tirtayasa \\ Email: andriana1188@untirta.ac.id
}

\begin{tabular}{l}
\hline Info Artikel \\
\hline Sejarah Artikel: \\
Diserahkan 13 Januari 2020 \\
Direvisi 3 April 2020 \\
Direvisi 6 Mei 2020 \\
Disetujui 22 Mei 2020 \\
\hline
\end{tabular}

Keywords:

students worksheet,

scientific contecxtual,

natural events and disaster,

mitigations

\section{Abstract}

This research aims to developing students worksheet based on scientific-contextual, by knowing the feasibility of the product being developed.

This research was conducted in the $5^{\text {th }}$ grade of Karang Tumaritis primary school in the science subject with natural events and disaster mitigation material on KD 3.8 Explains the events of the rotation and revolution of the earth and the occurrence of lunar eclipses and solar eclipses. Indicators 3.3.1 Identify natural events, 3.3.2 Discuss the impact of disasters and ways of disaster mitigation, 3.3.3 Simulate the mitigation of natural disasters that occur in Indonesia. The research used a method of research and development with the $3 D$ model that consists of defining, designing, and developing.

Based on the feasibility test of student worksheets conducted by the experts' team, obtained an average score of feasibility by science learning experts team is $84 \%$ with "Very Feasible" category of interpretation, the average score of feasibility by the learning media expert team is $78.4 \%$ with the "Feasible" interpretation category, and the average score of feasibility by the linguist team is $85.3 \%$ with "Very Feasible" category of interpretation.

\begin{abstract}
Abstrak
Penelitian ini bertujuan untuk mengembangkan Lembar Kerja Peserta Didik (LKPD) berbasis saintifik kontekstual, dengan mengetahui kelayakan terhadap produk yang dikembangkan.

Penelitian ini dilakukan di kelas V SDN Karang Tumaritis pada mata pelajaran IPA materi peristiwa alam beserta mitigasi bencana yang terdapat pada KD 3.3 Mengidentifikasi perubahan yang terjadi di alam, hubungannya dengan penggunaan sumber daya alam, dan pengaruh kegiatan manusia terhadap keseimbangan lingkungan sekitar. Indikator 3.3.1 Mengidentifikasi peristiwa alam, 3.3.2 Mendiskusikan dampak terjadinya bencana dan cara mitigasi bencana, 3.3.3 Mensimulasikan mitigasi bencana alam yang terjadi di Indonesia. Metode penelitian yang digunakan adalah metode penelitian dan pengembangan (Research and Development) dengan model 3D yang terdiri dari pendefinisian (Define), perencanaan (Design), dan pengembangan (Develop).

Berdasarkan uji kelayakan LKPD yang dilakukan oleh tim ahli, diperoleh skor rata-rata kelayakan oleh tim ahli pembelajaran IPA yaitu $84 \%$ dengan kategori interpretasi "Sangat Layak", skor rata-rata kelayakan oleh tim ahli media pembelajaran yaitu $78,4 \%$ dengan kategori interpretasi "Layak", skor rata-rata kelayakan oleh tim ahli bahasa yaitu 85,3\% dengan kategori interpretasi "Sangat Layak".
\end{abstract}

(C) 2020 Universitas Muria Kudus 
Encep Andriana, Trian Pamungkas Alamsyah, dan Injilya Tambun

PENGEMBANGAN LEMBAR KERJA PESERTA DIDIK BERBASIS SAINTIFIK ...

REFLEKSI EDUKATIKA: Jurnal Ilmiah Kependidikan, Volume 10, Nomor 2, Juni 2020, hlm. 163-171

\section{PENDAHULUAN}

Pembelajaran yaitu suatu usaha sadar yang dilakukan oleh guru atau pengajar untuk membimbing anak didiknya agar mereka dapat belajar sesuai dengan kebutuhan dan minatnya. Menurut Susanto (2015) pembelajaran merupakan bantuan yang diberikan pendidik agar terjadi proses pemerolehan ilmu dan pengetahuan, penguasaan, kemahiran, dan tabiat, serta pembentukan sikap dan keyakinan pada peserta didik. Pembelajaran yang berkualitas adalah pembelajaran yang tepat sasaran sesuai dengan standar kompetensi lulusan. Sasaran tersebut mencakup pengembangan ranah sikap, pengetahuan, dan keterampilan yang dielaborasikan dalam proses pembelajaran (Kemendikbud, 2016).

Proses pembelajaran merupakan sebuah kegiatan timbal balik antara guru dengan siswa. Asrori, Setyo Budi dan Triyono (2012) berpendapat bahwa aktivitas belajar merupakan salah satu bagian dalam proses pembelajaran, karena dengan aktivitas belajar maka siswa akan mendapatkan pengalaman baru dalam belajarnya. Hal tersebut berlaku pada setiap pembelajaran dalam ruang lingkup belajar, satu diantaranya pada pembelajaran Ilmu Pengetahuan Alam (IPA).

Pembelajaran IPA merupakan pembelajaran yang menekankan pada pemberian pengalaman belajar secara langsung melalui kegiatan pengamatan dan percobaan. Trianto (2010) berpendapat bahwa IPA adalah suatu kumpulan teori yang sistematis, penerapannya secara umum terbatas pada gejala-gejala alam, lahir, dan berkembang melalui metode ilmiah seperti observasi dan ekperimen serta menuntut sikap ilmiah seperti rasa ingin tahu, terbuka, jujur, dan sebagainya. Tujuan pembelajaran IPA bukan semata-mata hanya pada penguasaan materi dan menghafal fakta-fakta yang tersaji dalam buku saja, melainkan lebih menekankan kepada pemberian pengalaman langsung untuk jangka panjang. Dengan konsep ini, diharapkan siswa mendapatkan hasil belajar yang lebih bermakna dan proses pembelajaran berlangsung secara alamiah dengan melibatkan pengalaman siswa secara langsung melalui suatu kegiatan bukan hanya sekedar pemindahan pengetahuan dari guru ke siswa.

Konsep pembelajaran IPA di Sekolah Dasar umumnya hanya sekedar pemindahan pengetahuan dari guru ke siswa dan tidak melibatkan pengalaman siswa secara langsung. Hal tersebut dapat membuat siswa tidak menyukai pelajaran IPA karena materi sulit dipahami dan lebih bersifat hafalan teori-teori atau fakta-fakta. Oleh karena itu diperlukan adanya suatu perencanaan yang menarik, yang dapat membuat siswa tertarik dan menyukai pelajaran IPA, yang dikemas dalam bentuk Lembar Kerja Peserta Didik (LKPD).

Lembar Kerja Peserta Didik (LKPD) merupakan bagian dari bahan ajar yang digunakan oleh guru dan siswa dalam kegiatan belajar mengajar. Menurut Jamaludin (2017: 153) bahan ajar merupakan kumpulan dari materi-materi pelajaran yang disusun dan dikemas secara sistematis baik berupa cetak maupun non cetak yang dapat digunakan dalam belajar dan pembelajaran.

LKPD adalah bahan ajar cetak yang berisi petunjuk serta langkah-langkah kegiatan untuk menyelesaikan suatu permasalahan (Istikharah dan Zulkifli, 2017). Melalui penggunaan LKPD siswa akan mendapatkan pengalaman langsung melalui kegiatan praktik yang dilakukannya. Pemberian pengalaman langsung pada siswa akan memudahkan siswa dalam memahami dan mengingat suatu materi.

Penggunaan LKPD dapat membantu peserta didik lebih efektif dalam proses pembelajaran, membangkitkan minat peserta didik dalam belajar, meningkatkan motivasi belajar dan rasa ingin tahu, serta meningkatkan kemampuan peserta didik dalam memecahkan masalah (Widjajanti, 2010). LKPD seharusnya bukan hanya sekedar lembar soal saja, tetapi berisi tentang rangkuman materi, petunjuk langkah-langkah percobaan yang harus siswa lakukan secara sistematis untuk membantu menemukan konsep-konsep pembelajaran melalui aktivitas yang dilakukan, dan soal-soal produktif sebagai latihan pengembangan bagi siswa. Akan tetapi, berdasarkan hasil wawancara yang telah dilakukan di SDN Karang Tumaritis, guru hanya menggunakan LKPD yang berisikan lembar soal-soal kognitif saja sehingga pada proses pembelajaran peserta didik cenderung pasif. Berdasarkan hal tersebut, diperlukan upaya untuk mengatasi masalah yang dihadapi yaitu dengan mengembangkan LKPD IPA berbasis Saintifik Kontekstual yang tidak hanya berisi soal-soal 
Encep Andriana, Trian Pamungkas Alamsyah, dan Injilya Tambun PENGEMBANGAN LEMBAR KERJA PESERTA DIDIK BERBASIS SAINTIFIK ... REFLEKSI EDUKATIKA: Jurnal Ilmiah Kependidikan, Volume 10, Nomor 2, Juni 2020, hlm. 163-171

kognitif, tetapi juga melibatkan kemampuan afektif dan psikomotorik siswa.

LKPD IPA berbasis Saintifik Kontekstual merupakan LKPD yang didesain dengan menggunakan pendekatan pembelajaran Saintifik Kontekstual pada komponen-komponenya. LKPD ini akan dikemas secara ilmiah dengan memasukkan unsur 5M (Mengamati, Menanya, Mencoba, Menalar dan Mengkomunikasikan) serta contoh-contoh yang berkaitan dengan lingkungan sekitar.

Keunggulan pada LKPD berbasis Saintifik Kontekstual ini yaitu kegiatan yang dilakukan melibatkan siswa untuk melakukan kegiatan mengamati, menanya, mencoba, menalar, dan mengkomunikasikan yang dapat menumbuhkan rasa ingin tahu siswa. Selain itu, LKPD ini juga dilengkapi dengan materi yang disesuaikan dengan peristiwa alam yang pernah terjadi di Indonesia khususnya di Provinsi Banten. Di dalam LKPD ini juga terdapat mitigasi bencana yang dapat memberikan pengetahuan kepada siswa bagaimana upaya penyelamatan diri, baik sebelum bencana, saat bencana dan setelah bencana terjadi.

LKPD berbasis Saintifik Kontekstual erat hubungannya dengan pemahaman siswa dalam proses pembelajaran. Hal tersebut sesuai dengan hasil penelitian yang dilakukan oleh Rahayuningsih (2018) yang mengatakan bahwa pembelajaran menggunakan LKPD dengan pendekatan Saintifik dapat membantu siswa dalam membangun pemahamannya sendiri dan dapat meningkatkan hasil belajar siswa. Selain itu hasil penelitian yang dilakukan oleh Winahyu (2016) menyatakan bahwa pendekatan Saintifik Kontekstual merupakan pendekatan pembelajaran yang efektif terhadap aktivitas dan hasil belajar siswa. Siswa menujukkan perilaku aktif dalam melaksanakan kegiatan pembelajaran seperti mengamati, menanya, mencoba, menalar, dan mengkomunikasikan.

Dilihat dari karakteristiknya, LKPD berbasis Saintifik Kontekstual cocok untuk diterapkan pada materi peristiwa alam dan mitigasi bencana. Hal tersebut dikarenakan pada materi peristiwa alam dan mitigasi bencana dapat menjalankan kegiatan $5 M$ dari pendekatan Saintifik yaitu mengamati, menanya, mencoba, menalar, dan mengkomunikasikan. Bencana alam seperti tsunami, gempa bumi, banjir, tanah longsor, puting beliung, gunung meletus sering terjadi di Indonesia sehingga siswa diharapkan dapat menyelamatkan diri ketika terjadi bencana. Kegiatan ini sangat penting dalam membangun pengetahuan awal siswa.

Berdasarkan hal-hal di atas, perlu dilakukan penelitian dengan judul "Pengembangan LKPD Berbasis Saintifik Kontekstual pada Materi Peristiwa Alam Beserta Mitigasi Bencana Pada Mata Pelajaran IPA Kelas V". Dimana LKPD ini diharapkan dapat menarik perhatian siswa dan meningkatkan aktivitas siswa dalam pembelajaran IPA.

\section{METODE PENELITIAN}

Penelitian ini dilaksanakan di SDN Karang Tumaritis dengan metode penelitian yang digunakan adalah metode penelitian pengembangan (Research and Development) dengan model 3D. Model pengembangan 3D memiliki 3 tahap pengembangan, yaitu: 1) tahap Define (pendefinisian), 2) tahap Design (perencanaan), dan 3) tahap Develop (pengembangan).

Prosedur pengembangan yang digunakan penelitian ini adalah prosedur pengembangan menurut Thiagarajan. Sugiyono (2015) menjelaskan langkah-langkah pengembangan menurut Thiagarajan:

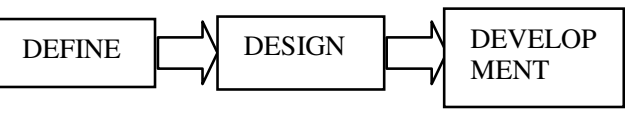

Gambar 1. Langkah-langkah penelitian dan pengembangan menurut Thiagarajan (Sugiyono 2015).

Sugiyono (2012) menyatakan bahwa penelitian berawal dari adanya potensi atau masalah yang terjadi di lapangan. Setelah potensi atau masalah dapat ditunjukkan secara factual atau krusial, maka selajutnya dilakukan pengumpulan data.

Tahap Define (Pendefinisian) adalah tahap dimana peneliti mengidentifikasi permasalahan-permasalahan yang dihadapi di sekolah. Hasil identifikasi permasalahan tersebut kemudian dianalisis dan ditemukan permasalahan-permasalahan yang dihadapi. Salah satu permasalahan yang dihadapi guru 
Encep Andriana, Trian Pamungkas Alamsyah, dan Injilya Tambun

PENGEMBANGAN LEMBAR KERJA PESERTA DIDIK BERBASIS SAINTIFIK ...

REFLEKSI EDUKATIKA: Jurnal Ilmiah Kependidikan, Volume 10, Nomor 2, Juni 2020, hlm. 163-171

adalah guru mengalami kesulitan dalam menyampaikan materi khususnya pembelajaran IPA yang menekankan kegiatan $5 \mathrm{M}$ pada pendekatan saintifik.

Tahap Design (Perencanaan) yaitu tahap merencanakan dan membuat desain produk berupa pengembangan Lembar Kerja Peserta Didik (LKPD) berbasis saintifik kontekstual pada pembelajaran IPA.

Tahap Develop (Pengembangan) yaitu tahap peneliti melakukan validasi kepada pakar ahli untuk menilai apakah produk perangkat pembelajaran yang dihasilkan sudah baik atau kurang baik untuk diujikan. Peneliti melakukan validasi produk Lembar Kerja Peserta Didik (LKPD) berbasis saintifik kontekstual yang dilakukan oleh tiga ahli yaitu ahli materi, ahli media dan ahli bahasa.

Teknik pengumpulan data yang diguakan penelitian ini adalah wawancara untuk mengetahui kebutuhan di sekolah. Untuk menguji kelayakan perangkat pembelajaran, instrument yang digunakan dalam penelitian dan pengembangan adalah lembar penilaian kelayakan instrumen Lembar Kerja Peserta Didik (LKPD) berbasis saintifik kontekstual pada mata pelajaran IPA di kelas 5 Sekolah Dasar.

Teknik analisis data yang digunakan dalam penelitian dan pengembangan dengan cara melakukan valiadasi instrumen sesuai dengan kriteria validasi instrument pembelajaran kemudian mendeskripsikan hasil analisis datanya. Instrumen validasi berupa angket penilaian Lembar Kerja Peserta Didik (LKPD). Angket penilaian tersebut menunjukkan hasil penskoran secara kuantitatif. Kriteria penskoran dalam angket ditentukan berdasarkan tabel sebagai berikut (Suwanto, 2011).

Tabel 1. Pengambilan keputusan revisi perangkat pembelajaran

\begin{tabular}{ccc}
\hline $\begin{array}{c}\text { Tingkat } \\
\text { Pencapaian }\end{array}$ & Kualifikasi & Keterangan \\
\hline $81-100$ & Sangat layak & $\begin{array}{c}\text { Tidak perlu } \\
\text { direvisi } \\
\text { Tidak perlu } \\
\text { direvisi }\end{array}$ \\
L1-80 & Layak & Direvisi \\
$41-60$ & Cukup layak & Direvisi \\
$21-40$ & Kurang layak & Sangat \\
$0-20$ & kurang layak & Direvisi \\
&
\end{tabular}

Validasi produk dilakukan oleh tiga ahli pendidikan bertujuan untuk mengetahui kelayakan dan kualitas produk sebelum di uji cobakan, Lembar Kerja Peserta Didik (LKPD) berbasis saintifik kontekstual akan dilakukan revisi jika perolehan nilai keseluruhan dari ahli bidang pendidikan $\leq 80$.

Uji coba produk dilakukan pada siswa kelas 5 SDN Karang Tumaritis. Uji coba dilakukan bertujuan untuk mengetahui respon siswa terhadap LKPD berbasis saintifik kontekstual apakah dapat digunakan sebagai bahan ajar atau tidak. Uji coba dilakukan oleh siswa dengan menggunakan LKPD dalam proses pembelajaran, kemudian mengumpulkan data melalui angket respon siswa.

\section{HASIL DAN PEMBAHASAN \\ Hasil}

Tahap pendefinisian dilakukan dengan mengidentifikasi permasalahan yang ada disekolah. Hasil identifikasi masalah tersebut yaitu tidak tersedianya bahan ajar yang mendukung pembelajaran IPA dengan pendekatan saintifik kontekstual sehingga membuat guru hanya menjelaskan materi dari buku tanpa adanya tambahan bahan ajar lain. Hal tersebut membuat pembelajaran menjadi tidak efektif dan siswa kurang memahami materi yang telah diajarkan.

Setelah dilaksanakan tahap pendefinisian kemudian dilanjutkan dengan tahap perencanaan produk yang akan dikembangkan. Tahap pertama dalam mengembangan Lembar Kerja Peserta Didik yaitu membuat rancangan awal isi LKPD. Setelah itu menentukan desain LKPD dengan tujuan agar konsisten dala pembuatannya. Mencari sumber informasi untuk pengembangan LKPD khususnya pada materi peristiwa alam beserta mitigasi bencana. Selanjutnya menambahkan ilustrasi dan gambar-gambar yang sesuai dengan materi sebagai pendukung dan penguat materi serta isi pada LKPD menjadi lebih menarik tahapan terakhir yaitu menambahkan komponen LKPD seperti kata pengantar, daftar isi, kompetensi dasar, petunjuk penggunaan, peta konsep dan daftar pustaka.

Setelah Lembar Kerja Peserta Didik selesai dikembangkan, dilaksanakan validasi produk yang dilakukan oleh beberapa ahli bertujuan untuk mengetahui kelayakan dan 
Encep Andriana, Trian Pamungkas Alamsyah, dan Injilya Tambun

PENGEMBANGAN LEMBAR KERJA PESERTA DIDIK BERBASIS SAINTIFIK ...

REFLEKSI EDUKATIKA: Jurnal Ilmiah Kependidikan, Volume 10, Nomor 2, Juni 2020, hlm. 163-171

kualitas produk sebelum di uji cobakan, Lembar Kerja Peserta Didik (LKPD) berbasis saintifik kontekstual akan dilakukan revisi jika perolehan nilai keseluruhan dari ahli $\leq 80$. Berikut ini adalah rekapitulasi para ahli terhadap Lembar Kerja Peserta Didik (LKPD) berbasis saintifik kontekstual pada mata pelajaran IPA.

Berikut adalah hasil validasi yang dilakukan oleh tim ahli.

Tabel 2. Hasil Validasi Ahli Materi

\begin{tabular}{ccc}
\hline No & Aspek yang diamati & $\begin{array}{c}\text { Penilaian } \\
\text { Ahli } \\
\text { Materi }\end{array}$ \\
\hline 1 & Relevansi Materi & 31 \\
\hline 2 & Kemutakhiran Materi & 25 \\
\hline 3 & Mendorong Keingintahuan & 28 \\
\hline & Jumlah & 84 \\
\hline & Persentase & $84 \%$ \\
\hline
\end{tabular}

Tabel 2 menunjukkan bahwa bahan ajar yang berupa Lembar Kerja Peserta Didik (LKPD) divalidasi oleh ahli materi pembelajaran IPA memperoleh skor $84 \%$ dan termasuk pada kategori "sangat layak" untuk di uji cobakan.

Hasil rata-rata penilaian belum mencapai $100 \%$ dikarenakan Lembar Kerja Peserta Didik (LKPD) yang dikembangkan masih terdapat beberapa kekurangan pada penyampaian materi diantaranya konsep bencana dan peristiwa alam yang masih belum dibedakan, pengertian peristiwa alam belum jelas, dan masih terdapat kalimat yang ambigu. Adapun untuk meningkatkan kualitas bahan ajar Lembar Kerja Peserta Didik (LKPD) yang dikembangkan dilakukan revisi produk sesuai saran validator.

Tabel 3. Hasil Validasi Ahli Media

\begin{tabular}{llc}
\hline No & Aspek yang diamati & $\begin{array}{c}\text { Penilaian } \\
\text { Ahli } \\
\text { Media }\end{array}$ \\
\hline 1 & $\begin{array}{l}\text { Kesesuaian LKPD dengan } \\
\text { tujuan pembelajaran }\end{array}$ & 15 \\
\hdashline 2 & Teknik Penyajian & 27 \\
\hline 3 & Desain & 40 \\
\hline 4 & Bahasa & 18 \\
\hline & Jumlah & 100 \\
\hline & Persentase $(\%)$ & $80,0 \%$ \\
\hline
\end{tabular}

Tabel 3 menunjukkan bahwa bahan ajar yang berupa Lembar Kerja Peserta Didik (LKPD) divalidasi oleh ahli media memperoleh skor $80,0 \%$ dan termasuk pada kategori "layak" untuk di uji cobakan.

Hasil rata-rata penilaian belum mencapai $100 \%$ dikarenakan Lembar Kerja Peserta Didik (LKPD) yang dikembangkan masih terdapat beberapa kekurangan pada desain media diantaranya cover pada Lembar Kerja Peserta Didik (LKPD) belum merepresentasikan isi, masih terdapat penggunaan gambar yang kurang tepat untuk menunjang teori, tidak ada sumber pada setiap reverensi gambar yang digunakan. Adapun untuk meningkatkan kualitas bahan ajar Lembar Kerja Peserta Didik (LKPD) yang dikembangkan dilakukan revisi produk sesuai saran validator.

Tabel 4. Hasil Validasi Ahli Bahasa

\begin{tabular}{|c|c|c|}
\hline No & Aspek yang diamati & $\begin{array}{c}\text { Penilaian } \\
\text { Ahli } \\
\text { Bahasa } \\
\end{array}$ \\
\hline 1 & Keterbacaan & 18 \\
\hline 2 & Kejelasan Informasi & 12 \\
\hline 3 & $\begin{array}{l}\text { Kesesuaian dengan kaidah } \\
\text { Bahasa Indonesia yang } \\
\text { baik dan benar }\end{array}$ & 13 \\
\hline 4 & $\begin{array}{l}\text { Pemanfaatan Bahasa } \\
\text { secara efektif dan efisien }\end{array}$ & 21 \\
\hline & Jumlah & 64 \\
\hline & Persentase (\%) & $85,3 \%$ \\
\hline
\end{tabular}

Tabel 4 menunjukkan bahwa bahan ajar yang berupa Lembar Kerja Peserta Didik (LKPD) divalidasi oleh ahli bahasa memperoleh skor $85,3 \%$ dan termasuk pada kategori "sangat layak" untuk di uji cobakan.

Hasil rata-rata penilaian belum mencapai $100 \%$ dikarenakan LKPD yang dikembangkan masih terdapat beberapa kekurangan pada segi bahasa diantaranya kalimat yang digunakan masih belum sepenuhnya mengikuti tata bahasa Indonesia yang sesuai dengan kaidah kebahasaan dan belum menstimulus siswa dalam mempertanyakan suatu hal lebih jauh dari materi yang disampaikan pada LKPD. Adapun untuk meningkatkan kualitas bahan ajar LKPD yang dikembangkan dilakukan revisi produk sesuai saran validator. 
Encep Andriana, Trian Pamungkas Alamsyah, dan Injilya Tambun PENGEMBANGAN LEMBAR KERJA PESERTA DIDIK BERBASIS SAINTIFIK ...

REFLEKSI EDUKATIKA: Jurnal Ilmiah Kependidikan, Volume 10, Nomor 2, Juni 2020, hlm. 163-171

Tabel 5. Hasil Validasi Respon Siswa

\begin{tabular}{llc}
\hline No & Aspek yang dinilai & $\begin{array}{c}\text { Penilaian } \\
\text { Siswa }\end{array}$ \\
\hline 1 & Isi Materi & $85,0 \%$ \\
\hline 2 & Bahasa & $87,5 \%$ \\
\hline 3 & Penyajian & $83,3 \%$ \\
\hline 4 & Kegrafikan & $87,5 \%$ \\
\hline & NP $(\%)$ Total & $85,8 \%$ \\
\hline
\end{tabular}

Tabel 5 menunjukkan bahwa bahan ajar yang berupa Lembar Kerja Peserta Didik (LKPD) divalidasi oleh siswa kelas 5 SDN Karang Tumaritis didapatkan hasil validasi aspek isi materi sebesar $85,0 \%$, aspek bahasa sebesar $87,5 \%$, aspek penyajian sebesar $83,3 \%$, aspek kegrafikan sebesar $87,5 \%$. Dengan demikian didapatkan hasil presentase respon siswa sebesar $85,8 \%$ dengan kriteria kategori interpretasi "sangat baik".

\section{Pembahasan}

Lembar Kerja Peserta Didik berbasis saintifik kontekstual ini merupakan penelitian dan pengembangan untuk menghasilkan bahan ajar yang lebih inovatif sehingga membuat siswa lebih aktif dalam pembelajaran. terdapat tiga tahapan dalam mengembangkan suatu produk menurut Thiagarajan (Sugiyono 2015: 38) yaitu tahap define, design, development. Tahap define yaitu mengidentifikasi permasalahan-permasalahan yang dihadapi di sekolah dengan cara observasi di kelas V SDN Karang Tumaritis, diketahui bahwa tidak tersedianya bahan ajar dan proses pembelajaran hanya menggunakan buku siswa berbasis Kurikulum 2013. Kegiatan belajar masih berpusat pada guru dan siswa terlihat pasif.

Salah satu manfaat dari Lembar Kerja Peserta Didik menurut Prastowo (2014 :270) yaitu dapat meminimalkan peran pendidik/guru namun dapat mengaktifkan siswa. Proses pembelajaran dengan menggunakan LKPD dapat membentuk siswa untuk aktif dan mandiri dalam proses pembelajaran.

Penggunaan pendekatan pembelajaran yang sesuai dengan materi merupakan salah satu faktor yang dapat mempengaruhi pembelajaran. dengan penggunaan pendekatan yang sesuai, maka membuat siswa lebih aktif dan dengan mudah mencapai tujuan pembelajaran. Pendekatan saintifik kontekstual merupakan pendekatan yang telah diterapkan pada kurikulum 2013 agar siswa dapat berpikir ilmiah yang dipadukan dengan kehidupan sehari-hari siswa.

Lembar Kerja Peserta Didik yang dikembangkan merupakan LKPD berbasis pendekatan saintifik kontekstuall yang terdiri dari kegiatan $5 \mathrm{M}$ yaitu mengamati, menanya, mencoba, menalar, dan mengkomunikasikan. Kegiatan tersebut berhubungan dengan kehidupan nyata siswa dengan lingkungan daerah yang pernah mengalami bencana seperti tsunami, gempa bumi, tanah longsor, banjir gunung meletus dan angina puting beliung.

Tujuan pengembangan dan penelitian ini adalah menghasilkan bahan ajar berupa LKPD berbasis saintifik kontekstual pada materi peristiwa alam beserta mitigasi bencana yang layak digunakan dalam proses pembelajaran. Uji kelayakan produk dilakukan dengan menggunakan instrumen angket yang didalamnya terdapat komentar, saran, dan kritik. Penilaian angket diperoleh dari hasil penilaian ahli materi, ahli media, ahli bahasa dan siswa kelas V SDN Karang Tumaritis Kota Serang sebagai subjek uji coba dan pengguna produk.

Bahan ajar LKPD yang telah dikembangkan dinilai oleh para ahli. Hasil penilaian validasi bahan ajar LKPD memperoleh nilai rata-rata $83 \%$ dengan kategori "sangat layak". Hasil rata-rata penilaian belum mencapai $100 \%$ hal ini dikarenakan LKPD yang dikembangkan masih terdapat beberapa kekurangan. Untuk itu peneliti melakukan revisi produk sesuai dengan saran validator agar dapat meningkatkan kualitas LKPD yang dikembangkan.

Hasil validasi oleh ahli materi mendapatkan presentase nilai akhir sebesar $84 \%$ dengan kategori "sangat layak". Penilaian oleh ahli materi ditinjau dari 3 indikator, yaitu: 1) Relevansi materi, 2) Kemutakhiran materi, 3) Mendorong keingintahuan. Hasil penilaian belum mencapai $100 \%$ dikarenakan LKPD yang dikembangkan masih terdapat beberapa kekurangan pada penyampaian materi diantaranya konsep bencana dan peristiwa alam yang masih belum dibedakan, pengertian peristiwa alam belum jelas, dan masih terdapat kalimat yang ambigu. 
Encep Andriana, Trian Pamungkas Alamsyah, dan Injilya Tambun

PENGEMBANGAN LEMBAR KERJA PESERTA DIDIK BERBASIS SAINTIFIK ...

REFLEKSI EDUKATIKA: Jurnal Ilmiah Kependidikan, Volume 10, Nomor 2, Juni 2020, hlm. 163-171

Hasil validasi oleh ahli media mendapatkan persentase nilai akhir sebesar $80 \%$ dengan kategori "layak". Penilaian oleh ahli media ditinjau dari 4 indikator, yaitu: 1) Kesesuaian LKPD dengan tujuan pembelajaran, 2) Teknik penyajian, 3) Desain, 4) Bahasa. Hasil penilaian belum mencapai $100 \%$ dikarenakan LKPD yang dikembangkan masih terdapat beberapa kekurangan pada desain media diantaranya cover LKPD belum merepresentasikan isi, masih terdapat penggunaan gambar yang kurang tepat untuk menunjang teori, tidak ada sumber pada setiap reverensi gambar yang digunakan.

Hasil validasi oleh ahli bahasa mendapatkan presentase nilai akhir sebesar $85 \%$ dengan kategori "sangat layak". Penilaian oleh ahli materi ditinjau dari 4 indikator, yaitu: 1) Keterbacaan, 2) Kejelasan informasi, 3) Kesesuaian dengan kaidah Bahasa Indonesia yang baik dan benar, 4) Pemanfaatan bahasa secara efektif dan efisien. Hasil penilaian belum mencapai $100 \%$ dikarenakan LKPD yang dikembangkan masih terdapat beberapa kekurangan pada segi bahasa diantaranya kalimat yang digunakan masih belum sepenuhnya mengikuti tata bahasa Indonesia yang sesuai dengan kaidah kebahasaan dan belum menstimulus siswa dalam mempertanyakan suatu hal lebih jauh dari materi yang disampaikan pada LKPD.

Setelah divalidasi dan direvisi selanjutnya diuji cobakan. Uji coba dilakukan kepada siswa kelas 5B SDN Karang Tumaritis. Presentase yang diperoleh dari hasil angket respon siswa sebesar $85,8 \%$, yang artinyaa respon siswa terhadp LKPD berbasis saintifik kontekstual yang dikembangkan sangat baik.

Hasil rata-rata presentase uji kelayakan bahan ajar LKPD secara keseluruhan didapatkan nilai uji kelayakan cukup tinggi yaitu $83,7 \%$. Menurut Purwanto $(2013 ; 103$ ) hasil persentase rata-rata yang diperoleh melalui uji validasi ahli masuk dalam kategori "sangat layak" sehingga bahan ajar LKPD ini layak digunakan untuk pembelajaran dikelas.

Hasil penelitian dan pengembangan bahan ajar Lembar Kerja Peserta Didik (LKPD) berbasis saintifik kontekstual sesuai dengan pendapat Prastowo (2014) yaitu alat bantu yang dapat memudahkan siswa memahami materi, memngaktifkan siswa dalam proses pembelajaran.
Hasil penelitian yang dilakukan memiliki persamaan dan perbedaan dengan penelitian Khamdun (2014), riset Khakim, Utaminingsih, dan Fakhriyah (2015), penelitian Wati, Utaminingsih, dan Fakhriyah (2015), riset Augraheni (2018), penelitian Malik (2019) serta riset Widiarta, Parmiti, dan Margunayasa (2019). Adapun persamaannya pada pemilihan mata pelajaran IPA dan Pengembangan LKPD yang dilakukan. Sementara itu perbedaannya pada subyek, fokus dan rumusan penelitian.

Penelitian Khamdun (2014) menyimpulkan bahwa metode inkuiri terbimbing dalam pembelajaran IPA dapat meningkatkan hasil belajar siswa. Selanjutnya riset Khakim, Utaminingsih, dan Fakhriyah (2015) menyimpulkan bahwa penerapan model CTL dapat meningkatkan hasil belajar IPA siswa materi sifat-sifat cahaya di kelas V SD 1 Peganjaran.

Penelitian Wati, Utaminingsih, dan Fakhriyah (2015) penerapan model Pembelajaran Berbasis Masalah (PBM) dapat meningkatkan hasil belajar IPA siswa materi daur air di kelas V SD Negeri Pasuruhan Pati. Selanjutnya Riset Augraheni (2018) menemukan bahwa Hasil validasi ahli dan praktisi menunjukkan bahwa Rencana Pelaksanaan Pembelajaran yaitu 87,62 berada pada kategori baik dan Lembar Kerja Siswa (LKS) yaitu 81,90 berada pada kategori baik. Oleh karena itu perangkat pembelajaran matematika berbasis pendidikan karakter kreatif layak digunakan di kelas IV Sekolah Dasar.

Riset Malik (2019) menunjukan bahwa hasil belajar IPA tentang menggolongkan hewan berdasarkan jenis makanannya dengan menggunakan metode diskusi kelompok pada siswa kelas IV SD 1 Sidorekso dapat meningkat. Dari kondisi awal rata-rata nilai tes formatif 61,48 dengan persentase tuntas $29,63 \%$ dan persentase tifak tuntas $70,37 \%$. Hasil siklus I meningkat rata-rata 68,15 dengan persentase tuntas $66,67 \%$ dan persentase tidak tuntas $33,33 \%$. Hasil siklus II rata-rata naik menjadi 73,70 dengan persentase tuntas $96,30 \%$ dan persentase tidak tuntas 3,70\%. Selanjutnya penelitian Widiarta, Parmiti, dan Margunayasa (2019) menunjukkan bahwa: (1) rata-rata skor validasi silabus yaitu 4,73 , berada pada kualifikasi sangat baik, rata-rata skor validasi RPP yaitu 4,75, berada pada 
Encep Andriana, Trian Pamungkas Alamsyah, dan Injilya Tambun

PENGEMBANGAN LEMBAR KERJA PESERTA DIDIK BERBASIS SAINTIFIK ...

REFLEKSI EDUKATIKA: Jurnal Ilmiah Kependidikan, Volume 10, Nomor 2, Juni 2020, hlm. 163-171

kualifikasi sangat baik, rata-rata skor validasi LKPD yaitu 4,86, berada pada kualifikasi sangat baik, dan (2) perolehan hasil validitas perangkat (silabus, RPP, dan LKPD) menunjukkan bahwa perangkat yang telah dikembangkan memiliki kualifikasi sangat baik.

\section{SIMPULAN}

Berdasarkan hasil penelitian dan pengembangan yang telah dilakukan pada Lembar Kerja Peserta Didik (LKPD), maka hasil penelitian dan pengembangan ini dapat disimpulkan sebagai berikut.

1. Penelitian dan pengembangan terhadap modul berbasis saintifik kontekstual yang dilakukan berdasarkan tahapan Thiagarajan yaitu tahap Define (Pendefinisian), tahap Design (perencanaan), dan 3) tahap Develop (pengembangan). Produk yang dihasilkan dari penelitian ini berupa LKPD saintifik kontekstual untuk siswa kelas V SD.

2. Produk yang dikembangkan telah divalidasi dan revisi dengan perolehan nilai validasi ahli materi sebesar $84,0 \%$ dengan kriteria interpretasi "Sangat Layak", nilai ata-rata validasi ahli media sebesar $80,0 \%$ dengan kriteria interpretasi "Layak", nilai validasi ahli bahasa sebesar $85,3 \%$ dengan kriteria interpretasi "Sangat Layak".

3. Lembar Kerja Peserta Didik berbasis saintifik kontekstual pada materi peristiwa alam beserta mitigasi bencana yang telah dikembangkan dan menjadi produk akhir telah diuji coba secara terbatas pada siswa kelas V SDN Karang Tumaritis dengan perolehan nilai rata-rata respon siswa sebesar $85,8 \%$ dengan kriteria interpretasi "Sangat Baik".

\section{DAFTAR PUSTAKA}

Asrori, S. 2013. Penerapan Quantum Learning Untuk Meningkatkan Aktivitas Belajar Siswa Pada Mata Pelajaran PKn di Kelas V SD Negeri Kembangjatitengan 2 Kabupaten Sleman. Kalam Cendekia PGSD Kebumen, 2 (1).

Augraheni, Indri. 2018. Pengembangan Perangkat Pembelajaran Matematika
Berbasis Pendidikan Karakter Kreatif Di Sekolah Dasar. Refleksi Edukatika : Jurnal Ilmiah Kependidikan, 8 (2): 132138.

Istikharah, R., dan Zulkifli, S. 2017. Pengembangan Lembar Kegiatan Peserta Didik (LKPD) Kelas X SMA/MA pada Materi Pokok Protista berbasis Pendekatan Ilmiah. Jurnal Pendidikan Matematika dan Sains, 12 (1): 32-38

Jamaludin, Ujang. 2017. Pembelajaran Pendidikan IPS. Bekasi CV Nurani.

Kemendikbud. 2016. Salinan Lampiran Permendikbud No. 22 Tahun 2016 Tentang Standar Proses Pendidikan Dasar dan Menengah. Jakarta: Kemendikbud.

Khakim., Utaminingsih, Sri., dan Fakhriyah, Fina. 2015. Penerapan Model Contextual Teaching and Learning Melalui Pemanfaatan Lingkungan Sekitar Untuk Meningkatkan Hasil Belajar IPA Kelas V SD 1 Peganjaran Kudus. Refleksi Edukatika : Jurnal Ilmiah Kependidikan, 5 (1).

Khamdun. 2014. Peningkatkan Hasil Belajar IPA Melalui Inkuiri Terbimbing Pada Siswa SDN I Ngembalrejo Bae Kudus. Refleksi Edukatika : Jurnal Ilmiah Kependidikan, 4 (2): 1-9.

Malik, Jamaludin. 2019. Penerapan Metode Diskusi Kelompok Untuk Meningkatkan Hasil Belajar IPA Dan Aktivitas Siswa Kelas IV SD I Sidorekso Pada Materi Menggolongkan Hewan Berdasarkan Jenis Makanannya. Refleksi Edukatika : Jurnal Ilmiah Kependidikan, 9 (2): 128-133.

Prastowo. 2014. Pengembangan Bahan Ajar Tematik Panduan Lengkap Aplikatif. Jogjakarta: Diva Press.

Purwanto. 2013. Prinsip-prinsip dan Teknik Evaluasi Pengajaran. Bandung: Remaja Rosdakarya. 
Encep Andriana, Trian Pamungkas Alamsyah, dan Injilya Tambun

PENGEMBANGAN LEMBAR KERJA PESERTA DIDIK BERBASIS SAINTIFIK ...

REFLEKSI EDUKATIKA: Jurnal Ilmiah Kependidikan, Volume 10, Nomor 2, Juni 2020, hlm. 163-171

Susanto, Ahmad. 2015. Teori Belajar dan Pembelajaran di Sekolah Dasar. Jakarta: Prenadamedia Group.

Trianto. 2010. Model Pembelajaran Terpadu. Jakarta: Prestasi Pustaka.

Rahayuningsih, D. 2018. Pengembangan Lembar Kerja Peserta Didik (LKPD) Dengan Pendekatan Saintifik Untuk Meningkatkan Hasil Belajar Mata Pelajaran Ips Bagi Siswa Kelas IV Sekolah Dasar. Jurnal Kajian Pendidikan dan Hasil Penelitian, 4 (2): 20-21.

Sugiyono. 2016. Metode Penelitian Kuantitatif, Kualitatif, dan R\&D. Bandung: Alfabeta.

Suwanto. 2011. Manajemen Sumber Daya Manusia dalam Organisasi Publik dan Bisnis. Alfabeta. Bandung.
Wati, Nanik Istika., Utaminingsih, Sri., dan Fakhriyah, Fina. 2015. Penerapan Model Pembelajaran Berbasis Masalah (Pbm) Untuk Meningkatkan Hasil Belajar IPA Siswa di Kelas V SD Negeri Pasuruhan Pati. Jurnal Ilmiah Kependidikan, 5 (1): 1-7.

Widiarta, I Dewa Gede Putra., Parmiti, Desak Putu., dan Margunayasa, I Gede. 2019. Pengembangan Perangkat Pembelajaran Inkuiri Terbimbing Berbasis Aktivitas Higher Order Thinking Pada Kelas V Sekolah Dasar. Refleksi Edukatika : Jurnal Ilmiah Kependidikan, 10 (1): 2939.

Widjajanti. 2010. Kualitas Lembar Kerja Siswa. (Skripsi). Malang: Program Sarjana Universitas Negeri Malang.

Winahyu. 2016. Pengembangan LKS Berbasis Saintifik untuk Menumbuhkan Karakter Ilmiah. Jurnal Pendidikan, 9 (1): 74-81. 